\title{
Anti-Leptospira spp. antibodies in wild mammals in the municipality of Monte Mor, São Paulo State, Brazil
}

\section{Anticorpos anti-Leptospira spp. em mamíferos silvestres do município de Monte Mor, estado de São Paulo, Brasil}

\author{
André Antonio Cutolo ${ }^{1 *}$; Guido Gomes Wanderley²; Helio Langoni ${ }^{3}$; \\ Carlos Roberto Teixeira ${ }^{4}$
}

\section{Highlights:}

11 serogroups of Leptospira spp. circulate in wild mammals in the studied area.

Didelphis albiventris, the most abundant species, presented 35.9\% (14/39) of seropositivity.

Icterohaemorrhagiae serogroup was the most frequent among the reagent samples.

\begin{abstract}
Leptospirosis is a potentially fatal zoonosis caused by Leptospira bacteria. Some animal host species are adapted to specific serovars being potential carriers and environmental dispersers. From 2009 to 2011, 45 wild mammals (39 opossums Didelphis albiventris, four porcupines Sphiggurus villosus, one coypu Myocastor coypus and one capybara Hidrochoerus hidrochaeris) found by citizens in anthropic areas of Monte Mor municipality were captured, restrained and had sera samples collected for Leptospira antibody detection. The samples were titrated by the microagglutination technique (MAT) for different serogroups. A total of $35.56 \%$ (16/45) animals were reactive for Leptospira antibodies for 11 different serogroups. The most frequent serovar, among the 12 identified, was Icterohaemorrhagiae (6/16), followed by Gryppotyphosa (4/16) and Pyrogenes (2/16). Didelphis albiventris, the most abundant species in the study, had a prevalence of $35.9 \%$ (14/39) for Leptospira antibodies, while S. villosus had $0 \%(0 / 4), M$. coypus (1/1) and H. hydrochaeris (1/1) 100\%. Among the seropositive D. albiventris, $35.71 \%(5 / 14)$ and $28.57 \%$ (4/14) seroreacted for Leptospira interrogans species, serogroups Icterohaemorrhagiae and Gryppotyphosa respectively, indicating environmental contamination by these bacteria and the possibility of exposure and infection of humans and domestic animals in the studied area.
\end{abstract}

Key words: Leptospirosis. Opossum. Serology. Reservoir. Campinas metropolitan region.

\section{Resumo}

A leptospirose é uma zoonose potencialmente fatal causada por bactérias do gênero Leptospira. Espécies animais hospedeiras adaptadas a sorovares específicos podem ser portadoras e dispersoras ambientais da bactéria. De 2009 a 2011, 45 mamíferos silvestres (39 gambás Didelphis albiventris, quatro ouriços

\footnotetext{
1 Discente do Curso de Mestrado do Programa de Pós-Graduação em Animais Selvagens, Faculdade de Medicina Veterinária e Zootecnia, FMVZ, Universidade Estadual Paulista, UNESP, Campus de Botucatu, Botucatu, SP, Brasil. E-mail: cutoloandre@ yahoo.com

2 Prof., Faculdade de Medicina Veterinária do Centro Universitário Sul de Minas, UNIS, Varginha, MG, Brasil. E-mail: guidowanderley@yahoo.com.br

3 Prof. Dr., Departamento de Higiene Veterinária e Saúde Pública, FMVZ/UNESP, Campus de Botucatu, Botucatu, SP, Brasil. E-mail: helio.langoni@unesp.br

4 Prof. Dr., Departamento de Cirurgia Veterinária e Reprodução Animal, FMVZ, UNESP, Campus de Botucatu, Botucatu, SP, Brasil. E-mail: cr.teixeira@unesp.br

* Author for correspondence
} 
Sphiggurus villosus, um ratão-do-banhado Myocastor coypus e uma capivara Hidrochoerus hidrochaeris) encontrados por munícipes em áreas antrópicas de Monte Mor, SP, foram capturados, contidos e tiveram amostras de soro coletadas para detecção de anticorpos para Leptospira. As amostras foram tituladas pela técnica de soroaglutinação microscópica (MAT) para diferentes sorogrupos. Um total de 35,56\% (16/45) animais foram reagentes para presença de anticorpos para um total de 11 sorogrupos diferentes. O sorovar dominante mais frequente, dentre os 12 identificados, foi o Icterohaemorrhagiae (6/16), seguido de Gryppotyphosa (4/16) e Pyrogenes (2/16). Didelphis albiventris, espécie mais abundante no estudo, apresentou uma prevalência de 35,9\% (14/39) de anticorpos anti-Leptospira, enquanto $S$. villosus teve 0\% (0/4) e ambos M. coypus (1/1) e H. hidrochaeris (1/1) 100\%. Dentre os Didelphis albiventris avaliados, houve maior frequência de reatividade sorológica à Leptospira interrogans, sorogrupos Icterohaemorrhagiae, com 35,71\% (5/14) e Gryppotyphosa com 28,57\% (4/14), indicando contaminação ambiental por tais leptospiras e a possibilidade de exposição e infecção de humanos e animais domésticos para tais bactérias na área estudada.

Palavras-chave: Leptospirose. Gambá. Sorologia. Reservatório. Região metropolitana de Campinas.

Leptospirosis is a potentially fatal zoonosis of worldwide distribution caused by spirochete bacteria of the genus Leptospira. At present, there are more than 20 species of the bacterium, which are grouped in different serogroups that amount to more than 300 serovars (Picardeau, 2013). Domestic, wild and human animals are susceptible to the infection, which occurs mainly by contact of injured skin or mucous membranes with contaminated water. Animal species adapted to specific serovars can be asymptomatic renal carriers and permanent dispersers of Leptospira in the environment through urine; e.g., the rodent Rattus norvegicus associated with serogroup Icterohaemorrhagiae; dogs with Canicola; and bovines with Sejroe. Clinical leptospirosis usually occurs in cases of infection by serovars to which the host is not adapted (Levett, 2001).

In Brazil, the disease has a high incidence in humans, with 13,000 notifications, 3,500 confirmations and an average lethality of $10.8 \%$ of confirmed cases per year. Within these cases, serogroup Icterohaemorrhagiae is the most frequent and the most associated with severe conditions (Ministério da Saúde [MS], 2014). In domestic animals, it causes mainly reproductive problems, especially abortion in livestock and horses, whereas dogs can have severe acute illness and death similar to humans. Infected horses can also exhibit characteristic features of chronic uveitis (Adler, 2015).

Among wild animals, small mammals are considered important reservoirs of Leptospira in nature. As such, they can be important sources of infection for domestic animals and humans (Levett, 2001), as seen in different wild free-living mammals that were subjected to bacterial isolation or DNA identification of Leptospira from kidney or urine samples in Brazil, including rodents, dasypodids, carnivores and marsupials (Albuquerque, Martins, Medeiros, Lilembaum, \& Ribeiro, 2017; Fornazari, Langoni, Marson, Nóbrega, \& Teixeira, 2018; Vieira, Pinto, \& Lilembaum, 2018).

The present study aimed to evaluate the frequency of antibodies to Leptospira spp. and to identify the serogroups circulating in different species of wild mammals in an anthropic area in the municipality of Monte Mor, metropolitan region of Campinas, São Paulo State, Brazil, and thus indicate the possible existence of environmental contamination by these bacteria and the consequent risk of exposure and infection of other mammal species, including humans.

Monte Mor is located at $22^{\circ} 56^{\prime} 48^{\prime \prime} \mathrm{S}$ and $47^{\circ} 18^{\prime} 57^{\prime \prime} \mathrm{W}$, at an altitude of $560 \mathrm{~m}$ above the sea level. The climate is considered a high-altitude tropical Cwa type. The municipality's territory is crossed by the Capivari River, which belongs to 
the Tietê hydrographic basin. The estimated human population in the municipality is 58,508 inhabitants and its territorial area is approximately $240 \mathrm{~km}^{2}$ (Instituto Brasileiro de Geografia e Estatística [IBGE], 2019). Approximately $8.9 \mathrm{~km}^{2}$ (3.78\%) of the municipal territory is covered by native vegetation, consisting of $1.36 \mathrm{~km}^{2}$ of semideciduous Atlantic forest and $7.5 \mathrm{~km}^{2}$ of capoeira, which is distributed mainly on the banks of the Capivari and Capivari Mirim rivers, including an important part of the central urban area of the municipality (Sistema de Informações Florestais do Estado de São Paulo [SIFESP], 2019). The Capivari River is constituted mostly by floodplains, which are strongholds for wildlife fauna (Corbo, Macarrão, Penteado, \& Manzani, 2012)

The municipality borders the cities of Campinas, Hortolândia, Santa Bárbara D’Oeste, Sumaré, Indaiatuba, Elias Fausto and Capivari, located 122 $\mathrm{km}$ from the city of São Paulo. Together with 18 other municipalities, Monte Mor constitutes the Metropolitan Region of Campinas, which has a total of approximately 3.2 million inhabitants spread over an area of 3,645.6 km² (IBGE, 2019).

Wild animals found by residents in anthropic areas (rural, peri-urban and urban) in the municipality were captured in a convenience sample by the Zoonosis Control Unit of the municipality of Monte Mor from December 2009 to November 2011. These were physically restrained, anesthetized intramuscularly with a combination of tiletamine and zolazepam (Zoletil ${ }^{\circledR 50}$ ) at the dose of $25 \mathrm{mg} / \mathrm{kg}$ when necessary and clinically examined. Subsequently, blood was sampled from the animals by ventral caudal vein or cardiac puncture. The serum was obtained after centrifugation at 5,000 rpm for 5 min and kept frozen at $-20{ }^{\circ} \mathrm{C}$ until laboratory processing.

The capture of animals was an integral part of the routine activities of the Zoonosis Control Service of the municipality of Monte Mor and was approved by IBAMA SISBIO (approval no. 31724-1). The project was also approved by the Animal Ethics Committee (CEUA) of FMVZ of Unesp Botucatu Campus (approval no. 0115/2019).

Anti-Leptospira spp. antibodies in serum were detected and quantified by the microscopic agglutination test (MAT) against 30 different antigens belonging to 19 serogroups, namely, Australis, Autumnalis, Ballum, Bataviae, Canicola, Celledoni, Cynopteri, Djasiman, Grippotyphosa, Hebdomadis, Icterohaemorrhagiae, Javanica, Panama, Pomona, Pyrogenes, Sejroe, Shermani, Samaranga and Andamana. Samples with titers (T) $\geq 100$ were considered reactive. In case of reactivity against more than one type of serogroup/serovar, that with the highest titer was considered reactive. When coinciding titer values were detected for more than one serogroup, all were considered reactive (Fornazari et al., 2018). Prevalence was defined as the number of reactive animals within the total number of animals sampled for each species and their respective confidence intervals.

A total of 45 animals of four species of wild mammals were subjected to serological analysis for the detection and titration of antibodies to Leptospira.

The sample consisted of marsupials and rodents only, which were distributed as follows, according to the species: 39 (86.67\%) white-eared opossums (Didelphis albiventris, Didelphimorphia: Didelphidae), four (8.89\%) porcupines (Sphiggurus villosus, Rodentia: Erethizontidae), one $(2.22 \%)$ coypu (Myocastor coypus, Rodentia: Myocastoridae) and one (2.22\%) capybara (Hydrochoerus hydrochaeris, Rodentia: Caviidae).

Of the 45 wild evaluated animals, 16 (35.56\%) were reactive in serology, exhibiting antibody titers for Leptospira greater than or equal to 1:100 in MAT.

Didelphis albiventris showed a prevalence of $35.9 \%$ of reactive individuals (14/39). The two aquatic-rodent individuals evaluated in this study H. hidrochaeris $(\mathrm{n}=1)$ and M. coypus $(\mathrm{n}=1)$ were 
reactive, with a prevalence of $100 \%$, and the four specimens of $S$. villosus were non-reactive, with a serological prevalence of $0 \%$. Results of prevalence by evaluated species are described in Table 1.
The MAT-reactive animals had titers that ranged from 1:100 to $1: 400$, with positivity for 11 serogroups and four distinct genome species, as shown in Table 2.

\section{Table 1}

Seroreactivity to MAT and seroprevalence of anti-Leptospira antibodies in wild mammals Monte Mor, SP, Brazil

\begin{tabular}{lccccc}
\hline \multicolumn{1}{c}{ Species } & R & NR & Total & Prevalence & CI \\
\hline Didelphis albiventris & 14 & 25 & 39 & $35.90 \%$ & $21-51 \%$ \\
Sphiggurus villosus & 0 & 4 & 4 & $0 \%$ & - \\
Hydrochoerus hydrochaeris & 1 & 0 & 1 & $100 \%$ & - \\
Myocastor coypu & 1 & 0 & 1 & $100 \%$ & - \\
\hline
\end{tabular}

CI: Confidence interval; R: Reactant to MAT; NR: Non Reactant to MAT.

Table 2

Different Leptospira species (genomospecies), serogroups and predominant serovars, number (n) of reactant animals and respective antibody titers detected through MAT in the sera of wild mammals from Monte Mor, SP, Brazil

\begin{tabular}{|c|c|c|c|c|c|c|c|}
\hline \multirow{2}{*}{ Host } & \multirow{2}{*}{ Species } & \multirow{2}{*}{ Serogroup } & \multirow{2}{*}{ Serovar } & \multirow{2}{*}{$\mathbf{n}$} & \multicolumn{3}{|c|}{ Titer } \\
\hline & & & & & 100 & 200 & 400 \\
\hline \multirow[t]{10}{*}{ D. albiventris } & L. interrogans & Icterohaemorrhagiae & Icterohaemorrhagiae & 5 & 2 & 2 & 1 \\
\hline & L. kirshneri & Grippothyphosa & Grippothyphosa & 4 & 4 & & \\
\hline & L. interrogans & Pyrogenes & Pyrogenes & 2 & & 2 & \\
\hline & L. interrogans & Sejroe & Wolffi & 1 & & 1 & \\
\hline & L. biflexa & Andamana & Andamana & 1 & & 1 & \\
\hline & L. interrogans & Djasiman & Djasiman & 1 & 1 & & \\
\hline & L. santarosai & Shermani & Shermani & 1 & & 1 & \\
\hline & L. biflexa & Semaranga & Patoc & 1 & & 1 & \\
\hline & L. interrogans & Canicola & Canicola & 1 & 1 & & \\
\hline & L. kirshneri & Cynopteri & Cynopteri & 1 & 1 & & \\
\hline \multirow[t]{2}{*}{ M. coypus } & L. interrogans & Icterohaemorrhagiae & Icterohaemorrhagiae & 1 & 1 & & \\
\hline & L. kirshneri & Cynopteri & Cynopteri & 1 & 1 & & \\
\hline \multirow[t]{4}{*}{ H. hidrochaeris } & L. interrogans & Icterohaemorrhagiae & Icterohaemorrhagiae & 1 & 1 & & \\
\hline & L. interrogans & Pomona & Pomona & 1 & 1 & & \\
\hline & L. interrogans & Sejroe & Sejroe & 1 & 1 & & \\
\hline & 4 genomospecies & 11 serogroups & 12 serovars & 23 & 14 & 8 & 1 \\
\hline
\end{tabular}

*Seroreactive with same titer to at least two serovars from different serogroups (D. albiventris: 100 Djasiman/ Grippotyphosa; 100 Canicola/Cynopteri/Grippotyphosa; 200 Icterohaemorrhagiae/Pyrogenes; M. coypus: 100 Icterohaemorrhagiae/ Cynopteri; H. hidrochaeris: 100 Canicola/Pomona/Sejroe). 
The 14 out of 39 D. albiventris that proved reactive were positive for 10 different serogroups, with Icterohaemorrhagiae being the most frequent and the most dominant serovar in five animals: two with a titer of 1:100, two with a titer of 1:200 and one with a titer of 1:400. The second most prevalent serogroup was Gryppotyphosa, with four reactive animals, all of which showed a titer of 1:100. Pyrogenes was the third most commonly found serogroup in the sera of opossums, with two animals showing a dominant titer of 1:200. Other seven different serogroups were also diagnosed in the sera of dominant reactive opossums, all of which appeared in only one animal, as follows: Sejroe, Andamana, Shermani and Patoc, with a titer of 1:200; and Djasiman, Canicola and Cynopteri with a titer of $1: 100$.

As regards the rodents that tested reactive, the coypu showed titers of 1:100 for both serogroups Icterohaemorrhagiae and Cynopteri and the capybara showed a titer of 1:100 for three different serogroups, namely, Canicola, Pomona and Sejroe.

Icterohaemorrhagiae was the overall most frequent serogroup, appearing in $35.71 \%(5 / 14)$ of opossums and having the only antigen that showed a titer of 1:400. This is the most frequent Leptospira serogroup in Rattus norvegicus and also the main cause of human leptospirosis (Levett, 2001), indicating that these animals probably had contact with the urine of these rodents in the environment they inhabit.

Several studies done in Brazil show different results regarding the prevalence of antibodies to Leptospira as well as data from microbiological culture isolation and PCR of biological samples of opossums.

Fornazari et al. (2018) researched free-living animals caught in the municipality of Botucatu SP, Brazil, and found Didelphis albiventris as the most abundant among the 16 present species in the captures, corresponding to $63.1 \%(195 / 309)$ of the total. However, only $2 \%(3 / 195)$ showed antibodies to Leptospira in MAT, with titers for only four serogroups ranging from 1:100 (Autumnalis, Canicola and Icterohaemorrhagiae) to 1:200 (Grippotyphosa). When the results of PCR examination of urine from seronegatives were included, the authors observed that seven other specimens had DNA from the bacterium, totaling 10 positive opossums. This result indicates active infection and potential elimination of Leptospira in urine, increasing the prevalence of infection to $5 \%(10 / 195)$, a value well below the prevalence of $35.9 \%$ found in the Capivari River basin, in Monte Mor.

Similar to the reports of Fornazari et al. (2018), Horta et al. (2016) obtained a low prevalence of antibodies to Leptospira among 343 opossums (D. aurita and D. albiventris) captured in 18 municipalities in the state of São Paulo between 2003 and 2008 , with only $3.5 \%(11 / 343)$ of reactive sera and titers ranging from 1:100 to $1: 800$ for serovars Butembo (3/10), Mini (3/10), Castellonis (2/10), Icterohaemorrhagiae (1/10) and Grippotyphosa (1/10).

In a review article on leptospirosis in free-living wild animals in Latin America, Vieira et al. (2018) found a median prevalence of $6.5 \%$ for antibodies to Leptospira for Didelphis albiventris opossums (considering a total of 16 publications that totaled 878 specimens of the evaluated species), Pomona being the most prevalent serogroup.

Serological diagnostic techniques are not able to ensure that the reactive animal has an active, acute or chronic infection, or whether it had been infected in the past, having been exposed at any given time but then becoming free of the infection and having only an immunological memory. There exists also the possibility of nonspecific reactions at low titers.

Absence of serological reactivity is not synonymous with absence of infection. Reservoir host species of Leptospira, such as the brown rat ( $R$. norvegicus), can actively and chronically eliminate leptospires in the urine in large amounts 
without presenting agglutinating antibodies in the blood (Fratini et al., 2015), and the same can occur in capybaras (Albuquerque et al., 2017). Hosts not reactive in serology may still be in the immunological window period, i.e., they may be infected without yet having enough detectable antibodies for their quantification (Levett, 2001).

In addition to showing agglutinins for Leptospira at different levels of prevalence, as already mentioned, opossums are potential reservoirs of these bacteria, since they have been found carrying Leptospira in renal tissue and urine samples. Thus, they are able to actively eliminate the causative agent of leptospirosis in the environment, even being seronegative. Molecular diagnostic techniques such as PCR are sensitive and help to better detect the agent in biological tissues of the evaluated animals (Fornazari et al., 2018).

Culture isolation of Leptospira from opossums has been reported by various authors; for instance, by Silva et al. (2013), who obtained and characterized Leptospira borgpetersenii from $D$. albiventris in urine samples in Jaboticabal - SP, Brazil. In their review article, Vieira et al. (2018) reported the isolation of leptospires from the urinary tract of opossums of the genus Didelphis (Didelphis albiventris, Didelphis marsupialis and Didelphis sp.) by different researchers in Brazilian territory, all belonging to the serogroups Panama, Pomona, Gryppotyphosa, Mini, Pyrogenes, Ballum and Icterohaemorrhagiae.

The adaptability of opossums to relatively small living areas, including wild areas modified by humans, is relevant, and this was the only species of small, non-flying mammal found in a 10-ha urban forest fragment (Almeida, Torquetti, \& Talamoni, 2008). Furthermore, the solitary habit, versatility in occupying ground and tree altitudinal extracts, prolificacy associated with early non-seasonal sexual maturity, nocturnal habit and omnivorous eating habit make this group of synanthropic marsupials abundant in urban, peri-urban and rural areas. They are also present in areas of riparian vegetation, semideciduous primary forests and natural fields (Talamoni \& Dias, 1999). Human dwellings are also included in the list of opossum habitats, as observed in this and other studies (Cutolo, Teodoro, Ovallos, Allegretti, \& Galati, 2014).

In Monte Mor, during the study period, part of the evaluated animals were found inside human dwellings, mainly in backyards associated with areas with availability of food, such as orchards, chicken coops, as well as areas with food for dogs and cats. The search for sheltering places, especially by females with offspring, was also observed in opossums (Cutolo et al., 2014).

Sphiggurus villosus was the second species in frequency evaluated in the period. The porcupine is a rodent that inhabits the Atlantic forest of southeastern and southern Brazil, having predominantly nocturnal, solitary, herbivorous and arboreal habits. Except to defecate, for instance, porcupines rarely come to the ground, not even to drink water (Passamani, 2010), hydrating themselves mostly through the ingestion of green leaves.

This arboreal habit leads to less direct contact with soil moisture and potentially contaminated water bodies. Herbivorous feeding and hydrating via leaf ingestion reduce the chances of ingesting leptospires when compared with carnivorous and omnivorous habits. The solitary habit, in turn, lowers the probabilities of infection by direct contact with the urine of other infected animals (Vieira et al., 2018). These factors may explain the zero prevalence of antibodies against Leptospira in the four specimens of porcupine evaluated in the study.

Capybaras are rodents that inhabit the entire Brazilian territory, in wild but also urban areas always associated with watercourses. They are social, herbivorous animals that swim frequently. Due to their aquatic habit, capybaras are expected to be under high risk of infection by bacteria of the genus Leptospira, and it would be natural to find a 
high prevalence rate of antibodies to Leptospira in this species, as demonstrated by Albuquerque et al. (2017).

In the present study, the examined specimen was reactive in serology, with antibody titers of 1:100 for three different serogroups (Canicola, Pomona and Sejroe), showing probable previous exposure to these serovars.

Albuquerque et al. (2017) demonstrated, in a study carried out in a natural environment in the Amazon, in the Brazilian state of Acre, that capybaras showed antibodies against Leptospira, with positive PCR and/or bacterial culture. The animals were asymptomatic and chronic carriers of Leptospira-especially those of serogroup Icterohaemorrhagiae - and massively infected with these bacteria, effectively eliminating the bacteria in the environment.

Coypu is a semi-aquatic mammal native to southern South America, though not native to the state of São Paulo, and an invader in different countries of the world (Fratini et al., 2015). In the present study, the specimen captured in the municipality of Monte Mor proved to be reactive in serology for Leptospira, with a titer of 1:100 for serogroups Icterohaemorrhagiae and Cynopteri. This species is a Leptospira reservoir, with proven infection and elimination of the agent in the environment through its urine (Fratini et al., 2015).

The evaluated geographic region has a low natural vegetation cover (only $3.78 \%$ of its territory having preserved areas) (SIFESP, 2019), with the little existing vegetation being restricted mainly to riparian forests that serve as narrow fauna dispersion corridors squeezed between residences and the Capivari River. Interestingly, there is a concentrated use of these same areas by different wild species (Corbo et al., 2012).

The concentration of different species in restricted areas bathed by the Capivari River and its tributaries may explain the exposure of different species, especially aquatic and non-arboreal, to a riverside environment, flooded in the rainy season and permanently humid. The presence of opossums, capybaras and coypus reactive in serology for antibodies to Leptospira in the studied area is indicative of the bacterial environmental contamination in the area.

Icterohaemorrhagiae was the most frequent among the 11 Leptospira serogroups identified in the evaluated wild animals, suggesting a probable direct or indirect contact with Rattus norvegicus urine, especially from opossums. Isolation or identification of Leptospira from opossum urine characterizes this group of mammals as reservoirs of these bacteria (Silva et al., 2013; Fornazari et al., 2018; Vieira et al., 2018).

In visiting human dwellings, opossums pose a risk of transmission of Leptospira to humans and their pets. Eventually, the opposite route may take place, with opossums being infected by leptospires from dogs, which was observed in this study, where at least one opossum was found with serological titer dominant for serogroup Canicola.

Reactivity to other serogroups indicates contact with leptospires from other host species, as observed for opossums and capybara, which reacted to serogroup Sejroe, prevalent in the bovine species.

By measuring the frequency of infection of wild animals by Leptospira, we could determine their sentinel role for environmental contamination for at least 11 Leptospira serogroups in the anthropic environment of the studied area, especially among opossums and aquatic rodents such as capybara and coypu.

White-eared opossum (Didelphis albiventris) was the most frequent species in the captures and showed $35.9 \%(14 / 25)$ positivity in serology, suggesting high exposure of this species to Leptospira. Of these, there was a higher frequency of reactivity to serogroup Icterohaemorrhagiae, with $35.71 \% \quad(5 / 14)$, followed by serogroup Gryppotyphosa, with $28.57 \%(4 / 14)$ positivity in serology, indicating environmental contamination 
by those leptospires and the possibility of exposure and infection of humans and domestic animals by these bacteria. Further studies are needed to better characterize leptospirosis in the studied area.

\section{Acknowledgments}

This study was supported by the Coordination for the Improvement of Higher Education Personnel - Brazil (CAPES) - Finance Code 001. The author thanks the technical staff of the Zoonosis Control Unit of the municipal government of Monte Mor, especially Paulo Milani Júnior and Anna Karollina Menezes Teodoro. Thanks also to Professor José Carlos de Figueiredo Pantoja for the statistical review.

\section{References}

Adler, B. (2015). Leptospira and leptospirosis. Current Topics in Microbiology and Immunology, 387, 1-293. doi: 10.1007/978-3-662-45059-8

Albuquerque, N. F., Martins, G., Medeiros, L., Lilembaum, W., \& Ribeiro, V. M. F. (2017). The role of capybaras as carriers of leptospires in periurban and rural areas in the western Amazon. Acta Tropica, 169, 57-61. doi: 10.1016/j.actatropica.2017.01.018

Almeida, A. J., Torquetti, C. G., \& Talamoni, S. A. (2008). Use of space by neotropical marsupial Didelphis albiventris (Didelphimorphia: Didelphidae) in an urban forest fragment. Revista Brasileira de Zoologia, São Paulo, 25(2), 214-219. doi: 10.1590/ S0101-81752008000200008

Corbo, M., Macarrão, A., Penteado, M., \& Manzani, P. (2012). Monte Mor: a vida às margens do Capivari. Vinhedo: Editora Avis Brasilis.

Cutolo, A. A., Teodoro, A. K. M., Ovallos, F. G., Allegretti, S. M., \& Galati, E. A. B. (2014). Sandflies (Diptera: Psychodidae) associated with opossum nests at urban sites in southeastern Brazil: a risk factor for urban and periurban zoonotic Leishmania transmission? Memórias do Instituto Oswaldo Cruz, 109(3), 391-393. doi: 10.1016/j.vprsr.2019.100286

Fornazari, F., Langoni, H., Marson, P. M., Nóbrega, D. B., \& Teixeira, C. R. (2018). Leptospira reservoirs among wildlife in Brazil: beyond rodents. Acta Tropica, 178, 205-212. doi: 10.1016/j.actatropica.2017. 11.019
Fratini, F., Turchi, B., Ebani, V. V., Bertelloni, F., Galiero, A., \& Cerri, D. (2015). The presence of Leptospira in coypus (Myocastor coypus) and rats (Rattus norvegicus) living in a protected wetland in Tuscany (Italy). Veterinarski Arhiv, 85(4), 407-414. doi: 10.24099/vet.arhiv

Horta, M. C., Ragozo, A. M. A., Casagrande, R. A., Matushima, E. R., Souza, G. O., Morais, Z. M.,... Gennari, S. M. (2016). Occurrence of anti-Toxoplasma gondii, Neospora caninum and Leptospira spp. antibodies in opossums (Didelphis spp.) in São Paulo State, Brazil. Brazilian Journal of Veterinary Research and Animal Science, 53(3), 1-9. doi: 10.11606/issn.1678-4456.bjvras.2016.110381

Instituto Brasileiro de Geografia e Estatística (2019). Estado de São Paulo. Recuperado de http://www. ibge. com.br

Levett, P. N. (2001). Leptospirosis. Clinical Microbiology Reviews, 14(2), 296-326. doi: 10.1128/CMR. 14.2.296-326.2001

Ministério da Saúde (2014). Leptospirose: diagnóstico e manejo clínico. Brasília: Ministério da Saúde.

Passamani, M. (2010). Use of space and activity pattern of Sphiggurus villosus (F. Cuvier, 1823) from Brazil (Rodentia: Erethizontidae). Mammalian Biology, 75(5), 455-458. doi: 10.1016/j.mambio.2009.04.005

Picardeau, M. (2013). Diagnosis and epidemiology of leptospirosis. Médecine et Maladies Infectieuses, 43(1), 1-9. doi: 10.1016/j.medmal.2012.11.005

Silva, F. J., Silva, T. R., Silva, G. C. P., Santos, C. E. P., Alves, J. R. F., Jr., \& Mathias, L. A. (2013). Isolation of Leptospira borgpetersenii in synanthropic Didelphis albiventris in Jaboticabal, São Paulo, Brazil. Brazilian Journal of Veterinary Research and Animal Science, 50(6), 457-461. doi: 10.11606/ issn.1678-4456.v50i6p457-461

Sistema de Informações Florestais do Estado de São Paulo (2019). Inventário Florestal do Estado de São Paulo. Recuperado de http://www.iflorestal.sp.gov. $\mathrm{br} / \mathrm{sifesp} /$ inventario.html

Talamoni, S. A., \& Dias, M. M. (1999). Population and community ecology of small mammals in southeastern Brazil. Mammalia, 63(2), 167-181. doi: 10.1515/mamm.1999.63.2.167

Vieira, A. S., Pinto, P. S., \& Lilembaum, W. (2018). A systematic review of leptospirosis on wild animals in Latin America. Tropical Animal Health Production, 50, 229-238. doi: 10.1007/s11250-017-1429-y 